\title{
Synergy of Industrial Sector for the Implementation of MBKM Curriculum: Where Innovators and Investors Meet
}

\author{
Bambang Yulianto ${ }^{1,}$ Sujarwanto Sujarwanto ${ }^{2,}$ Harmanto Harmanto ${ }^{3,}$ Martadi \\ Martadi $^{4}$ Sueb Sueb ${ }^{5}$ Hasan Subekti ${ }^{6 *}$ \\ ${ }^{1}$ Department of Indonesian Language, Universitas Negeri Surabaya \\ ${ }^{2}$ Department of Special Education, Universitas Negeri Surabaya \\ ${ }^{3}$ Department of Civics Education, Universitas Negeri Surabaya \\ ${ }^{4}$ Department of Design, Universitas Negeri Surabaya \\ ${ }^{5}$ Department English Language Education Program, Universitas Negeri Surabaya \\ ${ }^{6}$ Department of Science Education, Universitas Negeri Surabaya \\ *Corresponding author. Email: hasansubekti@unesa.ac.id.
}

\begin{abstract}
The Government of Indonesia promotes the idea of independent learning (MB-KM) as the natural learning process to achieve student's autonomy for critical thinking, creativity, and collaborative skills. The purpose of this study is to map various forms of synergies between the higher education and industrial sector and job market (IDUKA) as a form of implementing MB-KM Curriculum. This qualitative research involved heads of the study programs in regards their strategy to engage with IDUKA. The responses show positive preference of $86.8 \%$ by revitalizing the curriculum involving IDUKA, and realignment to MB-KM shows a positive preference of $78.9 \%$. The data show the preference for implementing MB-KM Curriculum lies on collaboration programs, focusing on its implementation in lectures by involving IDUKA with various forms of supports, namely policy-making from leaders related to cooperation, management, governance, stakeholders, alumni users, and cooperation funds. The results of this study become the rationale for higher education to implement relevant MB-KM Curriculum.
\end{abstract}

Keywords: Industrial Sector, Job Market, MBKM Curriculum, Synergy.

\section{INTRODUCTION}

This study is intended to map the synergy between study programs and industrial sector as part of the implementation of independent learning program proposed by the Government. In addition, the synergy becomes the reference for curriculum revitalization of the respective programs. The essence of independent learning is to explore the potential of learners in innovating and improving the quality of learning independently [1]. In line with the government's program to promote Independent Learning-Freedom Campus (MB-KM) policy, higher education institutions should be transformed through harmonization of the primary indicators of performance (IKU) of higher education proposed by Ministry of Education and Culture [2].
The premise of MB-KM program proposed by the Minister of Education and Culture [3] is a new framework of thought in the field of education to respond to various and dynamic changes in various fields of life [4]. The policy is believed to be in line with the idea of Ki Hajar Dewantara (the Founding Father of Indonesian Education) as stated in his two books that one of the stated goals of education is to build independent human beings [5]. In current proposal of the MB-KM Program, it is expected that the program produces prospective graduates whose skills are comparable globally and ready to champion the challenges of life by developing thinking skills, creativity, capacity, personality, and student needs, as well as developing self-autonomy [4], with increasingly complex dynamics in the $21^{\text {st }}$ Century [6], and personalized learning modes to respond the needs of 
education towards the era of industrial revolution 4.0 [1]. MB-KM Program provides freedom to the students and encourages them to enhance their natural development and growth through learning activities that foster initiation, creativity and self-expression.

As the emerging economic-driven trends with fast and dynamic changes in technology and learning [7], it requires universities and higher education institutions to modify their existing study programs into adaptive and independent study programs. The idea of independent learning is as the natural learning process to achieve student's autonomy for critical thinking, creativity, and collaborative skills [1] and may provide benefits to the students themselves and communities [8]. Higher education institutions should propose a comprehensive policy regarding the Government's program of independent learning in order to accommodate the students and learning outcomes relevant with the job market and student's preferable skills.

This study is expected to give the overview of the synergy between academic sector (study programs) and the industrial sector and job market. The overview is expected to become the rationale for the curriculum revitalization of respective programs regarding the implementation of independent learning program proposed by the Government. This synergy between the industrial sector and the world of work is in line with the direction of higher education policies and strategies to support the policy and strategy directions of the Ministry of Education and Culture.

\section{METHODS}

This qualitative research involved respective heads of study programs at State University of Surabaya (Unesa) ( $\mathrm{N}=47)$. The university is currently managing seven faculties and two programs (Vocational Program and Postgraduate Program). Unesa stands as top 2 universities in Indonesia and is in a transition to implement the MB-KB in accordance with the program from the Ministry of Education and Culture. In regards to the implementation of the MBKM (Independent to Learn - Freedom Campus) curriculum, heads of study program have major roles in determining the strategy to collaborate with external parties, including the industrial and private sectors; the involvement of relevant parties is intended to gain inquiry for the construction and evaluation of the existing curriculum.

Data were collected from the heads of programs through an online open questionnaire distributed by the Office of Academic Affairs. The questionnaire consists of some information which are designed to overview the synergy between the study programs and the industrial sector and job market by mapping the strategy of curriculum revitalization of the respective study program, e.g., the urgency of revitalization and the involvement of IDUKA. Data were analyzed descriptively along with the existing regulations by the Ministry of Education and Culture and university's policies on the implementation of MBKM curriculum.

\section{FINDINGS AND DISCUSSION}

This section discusses two important information in relation with the synchronization of the curriculum of the study programs with the industrial sectors. The two discussions cover the urgency of the revitalization on when and how the revitalization was employed by the programs and the involvement of industrial sector and job market (graduate users) who the users are and what kind of involvement was accommodated by the program.

\subsection{Urgency of Curriculum Revitalization}

One of the significant breakthroughs of the MB-KM Program proposed by the Ministry of Education and Culture is to grant students with the rights to study or program courses and/or other academic activities outside the study program (home-base); this policy should be accommodated strictly and structurally by the host university (as outbound students) as well as the host campus [11]. This opportunity is intended to encourage the students to pursue and master various sciences and competences useful and relevant with their preference to prosper in the field work as they graduate later; this option might be subjective, however, through careful counseling and supervision supported with 
policies, students could be provided with relevant options yet still relevant with their learning outcomes of the study programs.

The measuring instrument to accelerate the implementation of MB-KM Program is stipulated in the Primary Indicators of Performance (IKU) document of higher education, especially on the indicator 2 [2]. One of the targets of the IKU is to improve the quality of curriculum and learning in order to accommodate the students. In this context, Unesa should ensure that revitalization of the curriculum should be appropriatelyexecuted, and the education and academic policies are carried out in accordance with the ideals of the nation, namely the intellectual life of the nation [12]. This is in line with the strategic strategies theme for university's development [13]. Thus, Unesa is required to be able to integrate various main issues of sustainable development in the learning activities, including the upcoming updated curriculum.

In addition, the researchers from Office of Academic Affairs focus on the transitional phase to the implementation of the MB-KM curriculum through the evaluation of the existing curriculum of the study programs [10]. The MB-KM program is also in line with the university's strategic plan canto the realization of cooperative partnerships domestically and internationally, becoming one recognized teaching university by 2025 [9]. Referring to the university's business plan 2020-2024, the implementation of MB$\mathrm{KM}$ Curriculum is believed to open the initiation to collaborate between the innovators and investors (industrial sector)

In regard to the trend, preference at the university are encouraged to conduct revitalization of their curriculum in order to meet with the expected issues and market. The results of the survey talking about the last time the study program carried out curriculum revitalization are presented in Figure 1.

Within July 2019-August 2021, $78 \%$ of the overall study programs have revitalized their curriculum to meet the trends along with the implementation of the MB-KM Curriculum. The number is dominated by undergraduate programs; postgraduate programs have not been required to implement the curriculum yet. The emerging Freedom to Learn trend in higher education is expected to be fully implemented two years since it was passed and proposed by the government in 2019, especially the undergraduate programs. One of the significant changes of the current curriculum is to accommodate the students to study or program outside the main campus, such as programming the courses at other universities, internships programs, community services, research, etc.

At one side, the freedom to attend academic activities outside campus is expected to broaden the horizon of the students. On the other side, careful consideration should be assured in order to meet the job market as well. Thus, the study programs are encouraged to consider the roles of the industrial sector and job market as one of the partners to collaborate in order to accommodate the students. The revitalization is expected to bridge the innovators and investors.

\subsection{The Involvement of Industrial Sector and Job Market}

Despite the fact there is a heated debate on whether the higher education should be more pragmatic to answer the trends or remain idealistic in the midst of industrialization. The current MB-KM curriculum development in Indonesia is one of the challenges in higher education [14] and the most important curriculum goal at the higher education level [15] as well as a deeper focus of learning in a more tangible community environment [16]. This is with the hope that in order to be successful in facing the challenges of the 21 st century, it takes a lot of special skills related to work and life [17]. Regarding the disruptive trend, higher education institutions are expected to shape revitalize its roles to suit the demands of the $21 \mathrm{st}$ century skills [18]. Based on this view, it is necessary to prepare qualified graduates who are able to compete globally and master technological developments which are fundamental for everyone and important for the future of a country [19]. Thus, it is urgent at the higher education level to prioritize and encourage acceleration related to the mastery of information and communication technology [20].

The results of the survey on study programs involving IDUKA (industrial sector and job market) show that $86.8 \%$ of the study programs (undergraduate and postgraduate programs) have involved IDUKA as part of their curriculum revitalization within 2019-2021. This number means postgraduate programs have started considering the involvement of IDUKA as part of their curriculum, especially postgraduate programs which required industrial internships and joint research.

There is a link and match between graduates of higher education not only with the business world and the industrial world but also with a future that is rapidly changing [21]. To realize this demand, the university provides strong support for the realization of cooperative partnerships from within and outside parties, nationally and internationally. The various forms of supports by the university to bridge the academic programs with the IDUKA are leadership policies to accelerate partnerships with industrial sectors, the adaptive organizational structure of the Unesa especially the cooperation management, and infrastructure facilities and cooperation funds. 
As the partnership between education and industrial sector is considered an important aspect in modern world [22], including in Indonesia [23], the higher education institutions should lead the efforts to fulfil and improve Human Resources (HR) who are able to answer global challenges and needs in accordance with the demands of technological developments and social developments [12]. Unesa in responding to global challenges and social developments by taking several strategic steps, including the implementation of cooperation by involving IDUKA in order to align the curriculum of educators and students' competence with the needs of industry or the field of absorption of graduates, cooperate with the central and regional governments in managing education funding programs, develop a mechanism of cooperation with relevant agencies in managing education, and organize cooperation management related to IDUKA.

Various involvement of IDUKA as part of the revitalization of the curriculum, namely determining graduate profiles and attributes (66\%), curriculum (external) evaluation (46.8\%), designing program learning outcomes $(46.8 \%)$, and curriculum sanctioning $(56 \%)$. The other contribution and involvement is in the area of public assessment to the curriculum, workload assessment, and the synchronization of academic timeline for internships.

In line with this, MB-KM is based on the principle of heutagogy learning that places students in charge of what they learn and when to learn and provides a framework for students to be responsible for being more advanced and adaptable to the potential of the environment, science, and technology. MB-KM is learning that develops maturity, autonomy, and independence of students. Students as subjects who are free and independent to determine the direction of their lives develop optimally in an atmosphere full of love, understanding hearts and effective personal relationships. MB-KM as self-determined learning and self-regulated learning based on constructivist learning thinking - learning that gives students the freedom to actively construct their own knowledge through social processes and real-life contexts.

Thus, MB-KM is one of the essential embodiments of student-cantered learning that provides challenges and opportunities for the development of creativity, capacity, personality, and student needs, as well as developing independence in seeking and finding knowledge through realities and field dynamics such as ability requirements, real problems, social interaction, collaboration, self-management, performance demands, targets and achievements.

\section{CONCLUSION AND SUGGESTION}

Scalar The survey has shown the preference of the study programs at Unesa for the implementation of the
MB-KM collaboration program, focusing on the involvement of the industrial sector and job market in the forms of various support, including through policymaking for the graduates, curriculum, and academic workload assessment. Based on the results of this study, several things can be suggested, including stakeholder involvement of industrial sector and of market in broader context such as research culture, research collaboration between lecturers and students and investors, and academic ethics and scientific writing as well as the development of various innovative learning that can be applied related to the MB-KM curriculum. This research us expected to become the basis for curriculum evaluation regarding the implementation of MB-KM, especially the involvement of innovators at campus with the investors at the industrial sector and job market. The prospective study should focus on practice, evaluation, and the development of the MB-KM curriculum at Indonesian context.

\section{AUTHORS' CONTRIBUTIONS}

This research activity is driven and directed by BAMBANG YULIANTO as vice-rector for academic affairs at Surabaya State University (Unesa). Then, SUJARWANTO and HARMANTO carry out the instruments and plan the research developed. MARTADI and HASAN SUBEKTI contributed to analysing data and writing manuscripts. Manuscript and grammatical improvements by SUEB and providing critical feedback in writing manuscripts.

\section{ACKNOWLEDGMENTS}

The authors express gratitude to the State University of Surabaya which has funded this study through strategic research scheme on the Primary Indicators of Performance (IKU) of higher education, especially the implementation of MB-KM curriculum.

\section{REFERENCES}

[1] A. Widiyono, S. Irfana, and K. Firdausia, "Implementasi Merdeka Belajar Melalui Kampus Mengajar Perintis Di Sekolah Dasar", Metodik Didaktik: Jurnal Pendidikan Ke-SD-an 6 (1) (2021) 102-107. DOI: https://doi.org/10.17509/md.v16i2. 30125

[2] Kemendikbud, Buku Panduan Indikator Kinerja Utama PTN. Jakarta: Dirjen Pendidikan Tinggi, 2020 .

[3] S. Andari, Windasari, A. C. Setiawan, and A. Rifqi, "Student Exchange Program Of Merdeka BelajarKampus Merdeka (MBKM) In Covid-19 Pandemic", Jurnal Pendidikan dan Pembelajaran 28 (1) (2021), 30-37. DOI: http://dx.doi.org/10.17977/um047v27i1 $2021 \mathrm{p} 030$ 
[4] Kemendikbud, Buku Panduan Merdeka Belajar Kampus Merdeka. Jakarta: Direktorat Jenderal Pendidikan Tinggi, Kementerian Pendidikan dan Kebudayaan, 2020.

[5] L. J. Putera and R. Sugianto, "Perception and optimism about two-semester off-campus internship program of the policy of kampus merdeka-merdeka belajar among university students", Journal of Languages and Language Teaching 8 (1) (2020) 264-275.

DOI: https://doi.org/10.33394/jollt.v\%vi\%i. 2756

[6] Kemendikbud, Panduan Penyusunan Kurikulum Pendidikan Tinggi Di Era Industri 4.0 Untuk Mendukung Merdeka Belajar-Kampus Merdeka. Jakarta: Direktorat Jenderal Pendidikan, 2020.

[7] H. Subekti, Aster: Model pembelajaran bioteknologi terintegrasi stem berlandaskan kearifan lokal patrap triloka untuk meningkatkan keterampilan penyelidikan dan literasi informasi serta mengembangkan komunikasi sains, Pendidikan Biologi, Universitas Negeri Malang, Malang, 2020.

[8] N. Siregar, R. Sahirah, and A. A. Harahap, "Konsep Kampus Merdeka Belajar Di Era Revolusi Industri 4.0", Fitrah: Journal of Islamic Education 1 (1) (2020) https://doi.org/10.53802/fitrah.v1i1.13 141-157.DOI:

[9] S. Sujarwanto, B. Purwoko, B. Setiawan, K. R. Adhe, Asrori, W. P. Saroinsong, Laporan Manajemen Kerja Sama Unesa Surabaya: Universitas Negeri Surabaya, 2021.

[10] B. Yulianto, B. Jatmiko, Harmanto, and Tsuroyya, Pengembangan Kurikulum Merdeka BelajarKampus Merdeka Universitas Negeri Surabaya,Surabaya: LP2M Universitas Negeri Surabaya, 2020, pp. 1-36.

[11] D. Kodrat, "Industrial Mindset of Education in Merdeka Belajar Kampus Merdeka (MBKM) Policy", Jurnal Kajian Peradaban Islam 4(1) (2021) 9-14. DOI: https://doi.org/10.47076/jkpis.v4i1.60

[12] Unesa, Rencana Peralihan Universitas Negeri Surabaya Menuju PTN BH. Surabaya: Universitas Negeri Surabaya, 2021.

[13] Unesa, Laporan Evaluasi Diri Universitas Negeri Surabaya. Surabaya: Universitas Negeri Surabaya, 2021.

[14] B. H. Prakoso, Z. Ramdani, and B. Rahmah, "Teacher's Perception on Merdeka Belajar Policy", Indonesian Journal of Educational Assessment 3(1) (2021) 128-137. DOI: https://doi.org/10.26499/ijea. v3i2.84

[15] K. Krishnapatria, "Merdeka Belajar-Kampus Merdeka (MBKM) Curriculum In English Studies
Program: Challenges And Opportunities", ELT in Focus 4 (1) (2021) 12-19. DOI: https://doi.org/ 10.33394/jk.v7i4.4031A

[16] I. Maipita, M. B. Dalimunthe, and G. H. Sagala, The Development Structure of the Merdeka Belajar Curriculum in the Industrial Revolution Era, in Proceedings of the International Conference on Strategic Issues of Economics, Business and, Education (ICoSIEBE 2020), Tadulako, 2020, pp. 145-151.

[17] M. Abdullah and K. Osman, "21st century inventive thinking skills among primary students in Malaysia and Brunei", Procedia - Social and Behavioral Sciences 9 (1) (2010) 1646-1651. DOI: https://doi.org/10.1016/j.sbspro.2010.12.380

[18] T. Ames, E. Reeve, G. Stewardson, and K. Lott, "Wanted for 21st century schools: renaissance STEM teacher preferred", Journal of Technology Education 28 (2) (2017) 19-30. DOI: http://doi.org/10.21061/jte.v28i2.a.2

[19] H. Kanematsu and D. M. Barry, STEM and ICT Education in Intelligent Environments. London: Springer International Publishing Switzerland, 2016.

[20] R. Adams, S. Martin, and K. Boom, "University culture and sustainability: Designing and implementing an enabling framework", Journal of Cleaner Production 171 (1) (2018) 434-445. DOI: http://doi.org/10.1016/j.jclepro.2017.10.032.

[21] R. Rodiyah, Implementasi Program Merdeka Belajar Kampus Merdeka di Era Digital dalam Menciptakan Karakter Mahasiswa Hukum yang Berkarakter dan Profesional, Seminar Nasional Hukum Universitas Negeri Semarang 7 (2) (2021), 425-434. DOI: https://doi.org/10.15294/snhunnes. v7i2.737

[22] E. Purwanti, Preparing the Implementation of Merdeka Belajar - Kampus Merdeka Policy in Higher Education Institutions, Proceedings of the 4th International Conference on Sustainable Innovation 2020-Social, Humanity, and Education (ICoSIHESS 2020), 518 (1) (2020) 384-391. DOI: https://doi.org/10.2991/assehr.k.210120.149

[23] E. Purwanti, "Preparing the Implementation of Merdeka Belajar - Kampus Merdeka Policy in Higher Education Institutions", Advances in Social Science, Education and Humanities Research 518 (1) (2020) 384-391. DOI: https://doi.org/10.2991/ assehr.k.210120.149 